\title{
„A tévé maradt az egyetlen lehetöség, ami lefoglalta öket" \\ - Hatéves kor alatti gyermekek és családjuk digitális eszközhasználatának változása a Covid19 járvány idején
}

\author{
F. Lassú Zsuzsa ${ }^{1}$ és Megyeriné Fácska Judit ${ }^{2}$ \\ ${ }^{1}$ Eötvös Loránd Tudományegyetem Tanító- és Óvóképző Kar Neveléstudományi Tanszék \\ ${ }^{2} Z$ uglói Egyesitett Bölcsődék
}

\begin{abstract}
Absztrakt
A 2020-ban kezdődött koronavírus-járvány az első év tavaszán teljes lezárást okozott a gyermekintézményekben. A szülők a világon mindenütt arra kényszerültek, hogy kiskorú gyermekeikről otthon gondoskodjanak, ami gyakran felborította a családok életet. Az otthonmaradt kisgyermekekkel való törődés és a munka nehezen sikeredő összeegyeztetése miatt az érintett családok gyermekei gyakrabban használtak, használnak digitális eszközöket. Kutatásunkban hat év alatti gyermekeket nevelö szülőket ( $N=391)$ vizsgáltunk a kisgyermekek médiaeszköz-használatával kapcsolatos általános és pandémia alatti „vészhelyzeti” nézetei és gyakorlata vonatkozásában, online kérdőív segítségével, kényelmi mintavétellel. Eredményeink szerint a megkérdezett családokban a kisgyermekek nagy része a járvány előtt is IKT-eszközhasználó volt, és a pandémia a vizsgált gyerekek 46\%-ánál képernyőidő-emelkedéssel járt. A digitális eszközhasználat általános szabályozásával kapcsolatban a kutatásban sikerült négy faktort feltárni, melyek közül a „megengedő, nem szabályozó” és az „ellenőrző, kontrolláló” faktorok mutattak összefüggést a járvánnyal összefüggő változásokkal. Az általános „megengedő, nem szabályozó” attitűd (amely az idősebb és kevésbé iskolázott szülők és az idősebb gyerekek esetén jobban jellemző), a járvány alatt is összefüggést mutat az IKT-eszközhasználat növekedésével a gyermekek körében Az általános „ellenőrző, kontrolláló” attitűd esetén, kutatásunk szerint, a szülő a krízisben sem engedte a gyermekek túlzott képernyőhasználatát. Eredményeink a szülők tudatosságának fokozására hívják fel a figyelmet a kisgyermekek túlzott médiaeszköz használatával összefüggésben.
\end{abstract}

Kulcsszavak: Covid19 járvány, koragyermekkor, megnövekedett digitális eszközhasználat, szülői szabályozás

A 21. század gyermekei kora gyermekkortól digitális eszközhasználók. A digitális eszközök használatában való jártasság, a digitális kompetencia fon- 
tossága már nem vitatott az iskoláskorú gyermekek nevelésével és oktatásával összefüggésben, sőt egyes szerzők már a digitális korszak gyermekeiről beszélnek - annak ellenére, hogy a digitalizációra alapuló generáció-megközelítés nem feltétlenül megalapozott (lásd Lénárd, 2015). Az iskoláskor előtti időszak ugyanakkor még mindig olyan fejlődési korszaknak tekintett, amelyben a valós (offline) térben való (nagy)mozgások és a valós tárgyakon végzett manipuláció kiemelkedő jelentőségü (lásd Porkolábné, 1992; Zeng et al., 2017). A valós, offline mozgást, manipulációt és a társas kapcsolatokban való tájékozódást szorítja vissza a digitális eszközhasználat minden életkorban, legkárosabb hatása mégis a hat év alatti gyermekek fejlődésében valószínüsíthető (Healey \& Mendelsohn, 2019). Különösen kitettek ennek a veszélynek azok a gyerekek, akik tartós vagy átmeneti okokból kevesebb figyelmet kapnak gondozóiktól, például egy világjárvány idején. Jelen tanulmányban a 2020 tavaszán elindult Covid19 járvány okozta korlátozások hatásával összefüggésben vizsgáljuk a hatévesnél fiatalabb gyermekek és családjuk digitális eszközhasználatában bekövetkezett változásokat. Kutatásunk célja, annak megmutatása, milyen hatással volt a pandémia időszaka a kisgyermekek digitális eszközhasználatára, valamint a szülők tudatosságára a médiahasználat korlátozásában.

\section{Digitális eszközhasználat hatásai kora gyermekkorban}

Egy 2015-ben végzett amerikai kutatás adatai alapján az egy év alatti gyermekek 96,9\%-áról nyilatkozott úgy a szülő, hogy a gyermek használ(t) valamilyen elektronikus médiaeszköz:t okostelefontetot, tablet, laptop stb. (Kabali et al., 2015). Kutatások alapján a médiaeszközök kora gyermekkori használata egyértelműen együtt jár a fizikai játékok használatának csökkenésével, a tanulási és magatartási zavarok és az elhízás valószínűségének megnövekedésével (Healey \& Mendelsohn, 2019). A megnövekedett kora gyermekkori digitális eszközhasználat emellett összefüggésbe hozható az agresszió nagyobb toleranciájával és ezen keresztül a gyakoribb agresszív viselkedéssel, csökkent empátiás készséggel (például Anderson \& Bushman, 2001). Bár vannak kutatási eredmények a digitális eszközök előnyös hatásairól, különös tekintettel a mozgásukban vagy érzékelésükben akadályozott gyermekek körében fejlesztési céllal használt technológiák esetén (Hsieh, 2008), a tipikusan fejlődő kisgyermekek és óvodások esetén nem igazolható az elektronikus médiaeszközök előnye a hagyományos szerepjáték eszközökkel és mozgásos játékeszközökkel, valamint a könyvből való meséléssel szemben (Milteer \& Ginsburg, 2012; Parish-Morris et al., 2013). A túlzott képernyőhasználatot a kutatók és a nevelési szakemberek egyaránt korai függőségként értelmezik (Kardaras, 2017).

Konok Veronika és munkatársai (2020) érintőképernyős mobileszközök használatának hatását vizsgálták óvodáskorú gyermekeknél és eredményeik szerint az érintett gyermekek egyrészt a szelektív figyelem, másrészt a társas helyzetekben alkalmazott összetett kognitív képességek (tudatelmélet) 
tekintetében mutattak elmaradást az ilyen eszközöket nem használó társaikkal szemben. Eredményeik értelmezésénél a kutatók kiemelik a kora gyermekkori digitális eszközhasználat káros hatását a társas kompetenciákra, amennyiben azok a társas helyzetektől vonják el a gyermekeket (Konok et al., 2020). Más kutatók szintén azt találták, hogy a tipikus képernyőhasználó gyermek kevesebbet beszél a szüleivel, a kortársaival és még önmagában is, mint a nem elektronikus játékot használó társa (Sosa, 2016).

Az érintőképernyős digitális eszközhasználattal legtipikusabb problémaként ugyanakkor a kézügyesség és téri tájékozódás csökkenését szokták összefüggésbe hozni, ami a két kéz egyidejü vagy váltott, a három dimenziós térben történő használata helyett általában csak az egyik (a domináns) kézzel végzett és kétdimenziós mozgásokat igényel (Greaves et al., 2012), és így hozzájárul a gyakori digitális eszközhasználó gyermekek iskolai tanulási nehézségeihez, különösen az írás és olvasás, téri tájékozódás területén (Hastings et al., 2009). Az Amerikai Gyermekgyógyászati Társaság 2019-es klinikai jelentése és ajánlása így fogalmaz: „ironikus, hogy amikor a pszichológusok és más fejlődéstudományi szakemberek felismerik a test fontosságát a tanulásban, a játékok egyre inkább kétdimenzióssá válnak" (Healey \& Mendelsohn, 2019, p. 5). Összefoglalóan elmondhatjuk, hogy a kisgyermekek digitális eszközhasználatára vonatkozó kutatások túlnyomó többségében kizárólag káros hatásokat azonosítottak, az esetleges korai fejlesztő hatások főleg a sajátos nevelési igényű gyermekek esetén azonosíthatók. Ennek ellenére a digitális eszközhasználat gyakorisága kora gyermekkorban egyre növekszik.

\section{A magyar kisgyermekek digitális eszközhasználata}

Egy 2018-ban végzett vizsgálat alapján a 8-38 hónapos gyermekek szülei szerint a gyermekek $72 \%$-a már használ valamilyen okoseszközt, többnyire okostelefont (Koscsóné \& Kiss, 2020). A digitális eszközhasználó (DE) gyerekek 40\%-a már másfél éves kora előtt kézbe vehette és „használhatta” szülei okostelefonját, a többiek 1,5-2 éves koruk között játszhattak vele először. A kutatásban vizsgált DE gyerekek szülei többnyire olyan helyzetekben adják oda az eszközt a gyerekeknek, amikor nem tudnak velük foglalkozni, és az eszközhasználatot valójában nem tudják ellenőrizni: például amikor anya/apa fóz, takarít, autót vezet, vagy amikor a gyermek önállóan játszik. Ehhez az ellenőrizetlenséghez hozzájárul még, hogy a szülők kevesebb mint 20\%-a telepített a készülékre szülői felügyeleti programot, ugyanakkor a DE gyerekek 70\%-a önállóan be tudja kapcsolni és használni az eszközt. Mindez összefüggésben áll azzal a ténnyel is, hogy a megkérdezett szülők alig 10\%-a tájékozódott arról, hogy milyen káros hatásai vannak a korai digitális eszközhasználatnak, és milyen megfontolásokat, ajánlásokat érdemes figyelembe venni kisgyermekek esetén. A szülők a gyermekorvosi és pszichológusi ajánlásokkal szemben az okoseszközt digitális cumiként használják, többnyire megnyugtatásként és figyelemelterelésként, illetve kevesebb mint 10\%-uk használja fejlesztési, tanulási célra. Mindennek 
ellenére a szülők (főleg a 30-39 közötti korosztályból) nagy része azt gondolja az okoseszköz használatának fejlesztő hatása van a gyermekekre, és csak kevesen (főleg a fiatalabb 18-29 éves szülők) gondolják ezeket a kütyüket károsnak a kisgyermekek fejlődésére (Koscsóné \& Kiss, 2020).

Hasonló eredményre jutottak B. Németh Mária és munkatársai (2021), akik óvodáskorú gyermekek szüleit kérdezték a gyermekek digitális eszközhasználatával összefüggésben feltételezett pozitív és negatív hatásokról. A vizsgálatban részt vevő szülők $86,79 \%$-a azt gondolja, hogy a digitális eszközhasználat óvodás korban hozzájárul a tudás megszerzéséhez, 32,9\%-uk említi a fejlődés és tanulás lehetőségét, kisebb arányban az információhoz való hozzáférést (15,79\%), és csak elenyésző volt azoknak az aránya, akik azt értékelik pozitívan ezekben az eszközökben, hogy az leköti és szórakoztatja a gyermeket (5,37\%). A szülők tehát óvodás korú gyermekeik kezébe adják a „kütyüket” és utólag pozitívan próbálják megindokolni döntésüket. Annál inkább szükség van erre az önigazolásra, mivel a válaszadók többsége látja a rizikót is a korai digitális eszközhasználatban. A szülők 63,24\%-a gondolja veszélyesnek az óvodáskori IKT-használatot a függőség és agresszió kialakulásával összefüggésben, több mint egyharmaduk látja a veszélyét a valós, fizikai játékoktól és mozgástól való eltávolodásban és a társas kapcsolatok csökkenésében, ezzel összefüggésben pedig a testi és lelki zavarok, szocializációs problémák kialakulásában (B. Német et al., 2021).

Janek Noémi (2019) szinte egyedülálló módon, a szülők mellett magukat az óvodás korú gyerekeket is vizsgálta kutatásában félig strukturált interjú és rajzvizsgálat módszerével, elsősorban az internettel és az ahhoz kapcsolódó eszközhasználattal összefüggésben. Százhúsz óvodást, elsősorban 5-7 éves gyermeket kérdezett ki és rajzoltatott azzal a nyílt kérdéssel, hogy „Szerinted, milyen az internet?". Eredményei alapján a gyermekek nagy része digitális eszközhasználó, és azok is rendelkeznek tudással az eszközök használatáról és az elérhető tartalmakról, akiknek nincs saját IKT-eszközük. A megkérdezett gyerekek főleg videókat néznek és játszanak ezeken az eszközökön, és többségük egyedül is használja azokat. Ebben a kutatásban sem volt jellemző a szülői kontroll megjelenése a gyermekek médiaeszköz használatával kapcsolatosan, és a szülők kis része olyannyira nem tudja szabályozni a gyermek eszközhasználatát, hogy az akár függőséget is jelezhet (Janek, 2019).

\section{A Covid19 járvány hatása a gyerekek digitális eszközhasználatára}

A 2020-ban kezdődött és világszerte milliók életét követelő koronavírus járvány az első év tavaszán teljes lezárást okozott a gyermekintézményekben. Szülők a világon mindenütt arra kényszerültek, hogy kiskorú gyermekeikről otthon gondoskodjanak, ami gyakran vezetett a gyermekek direkt vagy indirekt elhanyagolásához, rosszabb esetben mentális és fizikai egészségének veszélyeztetéséhez, még szélsőségesebb esetben családon belüli erőszakhoz, 
bántalmazáshoz (Bérubé et al., 2020), különösen azokban az esetekben, amikor a szülő a járvány előtt sem volt mentálisan egészséges, a pandémia pedig fokozta a mentális sérülékenység tüneteit (Lee et al., 2021).

Ugyanakkor még a leggondoskodóbb családokban is megnövekedett a stresszszint a betegségtől való szorongás vagy maga a betegség átélése, a munkahely esetleges elvesztése, a tér és a kapcsolatok beszűkülése, konkrét halálesetek következményeként. Mindezek közvetetten és közvetlenül is érintik a gyermekeket, akikkel szüleik az otthoni munkavégzés alatt sokkal kevesebbet tudtak foglalkozni, a kijárási korlátozások miatt kevesebb nagymozgásra, a családi élet terének esetleges zsúfoltsága miatt kevesebb vadulós játékra volt lehetőség, ami a kora gyermekkorban a társas kapcsolódás fontos eleme. Szintén a társas kapcsolatokat rombolta a kortárscsoporttal való találkozás lehetőségének csökkenése. Mivel kötötték hát le a gyerekek magukat és a szüleik őket? Többnyire digitális eszközökkel, amelyek túlzott használatát a pandémia a felnőtteknél is fokozta (Király et al., 2020). Az eddig elvégzett kutatások alapján a szakértők világszerte arra hívják fel a figyelmet, hogy a korlátozások és bezártság a gyermekek mentális egészségét még a felnőttekénél is jobban veszélyeztetik, hiszen éretlen idegrendszerük kevéssé képes az érzelmi szabályozásra, így kevésbé tudnak megbirkózni a járvány okozta megnövekedett stresszel (Montag \& Elhai, 2020). Különösen kontraproduktívnak, a káros hatásokat tovább növelőnek tartják a megnövekedett monitoridőt, amely a fontos érzelmi szabályozó rendszerek mủködését hátráltatja. (1. ábra)

\section{1. ábra}

A Covid19 járvány feltételezett hatása az elsödleges érzelmi rendszerek egyensúlytalanságára (Montag E Elhai, 2020, 3.o. alapján)

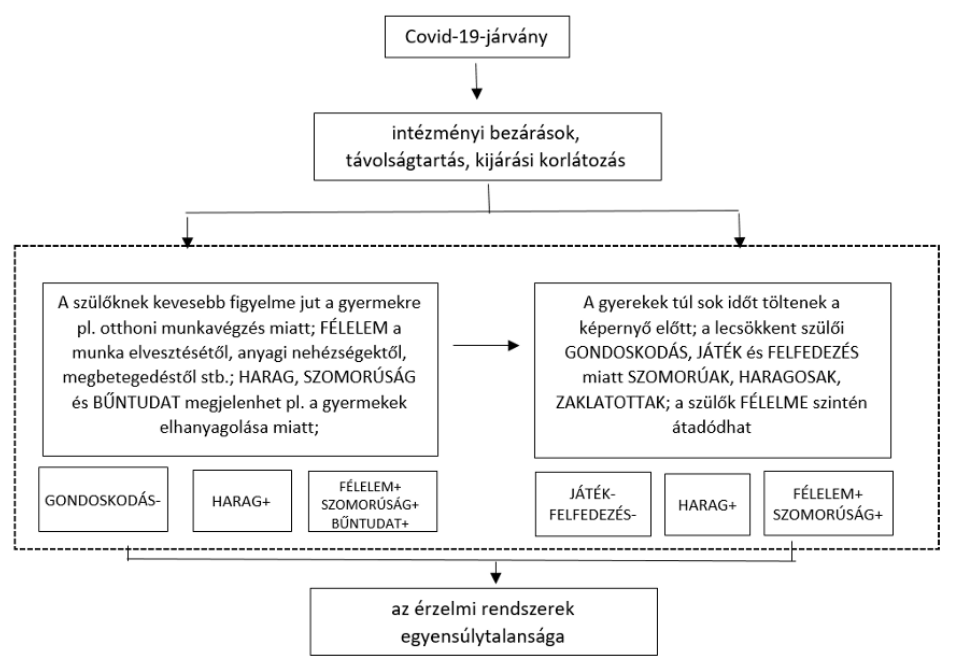


Mindezeket összefoglalva azt mondhatjuk, hogy az eddigi kutatások alapján a koronavírus-járvány világszerte megnövelte a digitális eszközhasználatot, főleg az iskoláskorú gyermekek esetén, azonban jó okunk van feltételezni, hogy a gyermekintézmények bezárásával a hat év alatti gyermekek is nagyobb monitoridőnek lettek kitéve, amit a szülők megnövekedett terhei és a bezártság valószínűsít. Mivel a Covid19 járvány vonatkozásában eddig kevés hazai vizsgálat készült erről a korosztályról (például Visnjic-Jevtic et al, 2021), ezért kutatásunkkal egyik elsőként kívántunk utánajárni a pandémia hatásának a kisgyermekek és óvodások digitális eszközhasználatára.

\section{Kutatás}

Kérdőíves kutatásunk célja a hat év alatti gyermekek és családjaik digitális eszközhasználatának vizsgálata a Covid19 járvány okozta hatásokkal összefüggésben. Kutatási kérdéseink a következők voltak:

- Mi jellemezte a pandémia előtt a családok digitális eszközhasználatát?

- Mi jellemzi általában a szülők hozzáállását a kisgyermekek és óvodások digitális eszközhasználatával kapcsolatban?

- Hogyan hatott a pandémia a szülők munkavégzésére és ezzel összefüggésben változott-e a szülői gondoskodás, felügyelet mértéke a gyermekek felé, különös tekintettel a kisgyermekek és óvodások digitális eszközhasználatára?

A kérdések megválaszolására online kérdőívet állítottunk össze, amelyet levelezőlistákon és a közösségi médián keresztül osztottunk meg a szülőkkel. A válaszadók toborzása kisgyermeknevelőkön és óvodapedagógusokon keresztül történt kényelmi mintavétellel, hólabdamódszerrel. A kérdőívben a szülők és családok demográfiai adatait, a családok digitális eszközellátottságát, az IKT-eszközök kisgyermekkori használatával kapcsolatos nézeteiket és gyakorlatukat, valamint a pandémia családra és digitális eszközhasználatra való hatását vizsgáltuk zárt végű kérdésekkel és skálákkal. A kérdőív kitöltése anonim volt és bármikor megszakítható, a vizsgálat során semmilyen személyazonosításra alkalmas érzékeny adatot nem gyüjtöttünk. A kutatásban való részvétel tájékozott beleegyezés alapján, önkéntesen történt, 18 év feletti válaszadók körében. A válaszokat 2020. április és 2021. március közötti időtartamban gyüjtöttük, lényegében lefedve a korlátozás bevezetése, lazítása és az újabb szigorítások bevezetése majd újbóli szigorítása folyamatát.

A kutatásban 391 fó vett részt, 21-57 év közötti szülők vagy szülői szerepben gyermeket nevelők. A válaszadók 93\%-a mint anya vett részt a vizsgálatban, mindössze 6,4\% volt az apák részvétele, és 1-1 fö testvér, illetve nagyszülő volt. A megkérdezett szülők 47,3\%-a csak egy gyermeket nevel, 38,6\%-uk kettőt, és három vagy több gyermeke a családok 14,1\%-ának van. A megkérdezett szülők 93,8\%-a párkapcsolatban, 6,2\%-a egyedül neveli gyermekét - amely adat pozitívabb számot mutat a 2011-es népszámlálási adatoknál, ahol a hatévesnél fiatalabb gyermekek 10\%-a nevelkedett egyszülős családban (KSH, 2011). 
A megkérdezett szülők nagy része $(63,8 \%)$ felsőfokú végzettséggel rendelkezik, ami szintén nem fedi le a népszámlálási adatok alapján elvárt gyakoriságot, és a hasonló online kutatások állandó korlátozó jellemzője. Középfokú végzettséggel a válaszadók 34,1\%-a, alapfokú végzettséggel mindössze 2,1\%-uk rendelkezett.

A kérdőív egy része egy (kiválasztott) gyermekre vonatkozóan kérdezte a szülők nevelői gyakorlatát a digitális eszközhasználattal összefüggésben. Ez a választott gyermek az esetek 20\%-ában három év alatti volt, 80\%-ban 3-6 év közötti. A választott gyermekek 55\%-ban fiúk és $45 \%$-ban lányok voltak. Az eredmények rögzítését és feldolgozását az IBM SPSS Statistics 26 program segítségével végeztük.

\section{Eredmények}

\section{Eszközellátottság és eszközhasználat}

A megkérdezett szülők 100\%-a válaszolta, hogy már a járvány előtt is rendelkeztek (digitális) médiaeszközökkel, legalább egy okostelefon vagy egy televízió minden családban volt. A 391 megkérdezett közül 213 fő (54,4\%) jelölte be az okostelefon/tablet és televízió/DVD-lejátszó kombinációk mellé az asztali számítógép/laptop/notebook eszközök valamelyikét, azaz a családok több mint felében minimum háromféle „képernyo”” állt rendelkezésre. A pandémia alatt a családok 24\%-a vásárolt új digitális eszközt, többnyire az otthonoktatás és otthoni munkavégzés érdekében. Azonban a 93 családból, akik új eszközt vásároltak 26-an (27\%) vettek kifejezetten szórakozási célú eszközt (játékkonzolt), azt azonban nem tudhatjuk, hogy a járvány nélkül is vásároltak volna-e ilyen eszközöket.

A kutatásba bevont hat év alatti gyermekek 28\%-a már a járvány előtt is rendelkezett saját IKT-eszközzel, 64 kisgyermeknek (16\%) van saját televíziója, 18\%-nak van saját tabletje vagy olyan okostelefon, amit ő (is) használ, 14 hat év alatti gyermek $(3,5 \%)$ rendelkezett saját játékkonzollal, és két kisgyermeknek volt saját laptopja vagy asztali számítógépe is.

Az eszközhasználatra vonatkozó általános kérdésekben arra kértük a szülőket, hogy skálán ítéljék meg, mennyire jellemző rájuk, hogy önmaguk is használják a digitális eszközöket a gyermekek jelenlétében, hogy törekszenek csak munkára használni azokat, hogy próbálnak lépést tartani a technológiai újításokkal stb. Az ötfokozatú skálán értékelt kérdésekre adott válaszok átlagából látható, hogy a válaszadó szülők, bár többségükben naponta használnak digitális eszközöket gyermekeik jelenlétében (átlag 4,24), általában közepes mértékben arra törekednek, hogy ezt az eszközhasználatot inkább a munkavégzésre szorítsák (átlag 2,76). A megkérdezett szülők inkább nem támogatják hat év alatti gyermekeik digitális eszközhasználatát, inkább nem használják a digitális eszközöket megnyugtatásra (átlag 1,98), és legkevésbé engedik az étkezések alatti kütyüzést (átlag 1,77). A gyermekek pandémia előtti digitális eszközhasználatára, annak szabályozására a második kérdésblokkban kérdeztünk rá. Megnyugtató eredmény, hogy a vizsgálatban részt vevő szülők átlagosan közepesnél jobban szabályozzák és ellenőrzik a gyer- 
mekek által fogyasztott tartalmakat (átlag 4,3), és - a korábbi kutatásban kapott eredményekkel ellentétben (Koscsóné \& Kiss, 2020) - ritkán használják az IKT-eszközöket jutalmazásra vagy unalomüzésre (átlag 2,5).

A két kérdésblokk összes kérdését faktoranalízissel vizsgálva négy szülői magatartásminta és hozzáállás körvonalazódik. A főkomponens-analízissel feltárt négy faktor a variancia 62,28\%-át magyarázza. (1. táblázat)

\section{1. táblázat}

A digitális eszközhasználat általános gyakorlatára és szabályozására vonatkozó kérdések faktoranalizisének eredménye

\begin{tabular}{|c|c|c|c|c|}
\hline \multicolumn{5}{|c|}{ A Főkomponens Analízis eredményea } \\
\hline & \multicolumn{4}{|c|}{ Komponensek } \\
\hline & $\begin{array}{l}\text { Megen- } \\
\text { gedö, } \\
\text { nem sza- } \\
\text { bályozó }\end{array}$ & $\begin{array}{l}\text { Ellenőr- } \\
\text { ző, kont- } \\
\text { rolláló }\end{array}$ & $\begin{array}{c}\text { Geek \& } \\
\text { gamer }\end{array}$ & $\begin{array}{l}\text { Digitális } \\
\text { luddita }\end{array}$ \\
\hline $\begin{array}{l}\text { Gyermekem unaloműzésre használta a } \\
\text { digitális eszközöket. }\end{array}$ & 800 & 120 & 034 &,- 139 \\
\hline $\begin{array}{l}\text { A gyermek(ek) kérésére mindig oda- } \\
\text { adom a digitális eszközöket. }\end{array}$ & ,796 &,- 150 & 147 & ,042 \\
\hline $\begin{array}{l}\text { Előfordult, hogy médiaeszközök oda- } \\
\text { adásával jutalmaztam vagy elvételével } \\
\text { büntettem gyermekem. }\end{array}$ & ,791 & 011 & ,030 & ,075 \\
\hline $\begin{array}{l}\text { A gyermek(ek) megnyugtatására is } \\
\text { használom a digitális eszközöket. }\end{array}$ & ,758 &,- 147 & ,096 & ,043 \\
\hline $\begin{array}{l}\text { Gyermekem önállóan kezelte a digitális } \\
\text { eszközöket. }\end{array}$ & ,704 & , 150 & 110 &,- 112 \\
\hline $\begin{array}{l}\text { Gyermekem napi szinten használt vala- } \\
\text { milyen médiaeszközt. }\end{array}$ & 681 & ,256 & ,114 &,- 091 \\
\hline $\begin{array}{l}\text { Szoktunk együtt játszani a gyermekem- } \\
\text { mel valamelyik digitális eszközön. }\end{array}$ & 631 &,- 010 & ,321 & ,088 \\
\hline $\begin{array}{l}\text { Étkezések alatt engedem a digitális } \\
\text { eszközök használatát. }\end{array}$ &, 567 &,- 085 & ,208 & ,215 \\
\hline $\begin{array}{l}\text { Ellenőriztük, hogy gyermekünk milyen } \\
\text { tartalmat néz(nek) készülékei(ke)n. }\end{array}$ & ,013 & ,900 &,- 010 & ,017 \\
\hline $\begin{array}{l}\text { Odafigyeltem az ajánlott korhatárjel- } \\
\text { zésre, amikor gyermekem médiaeszközt } \\
\text { használt, filmet nézett vagy játszott. }\end{array}$ & ,012 & ,828 & ,083 & ,201 \\
\hline $\begin{array}{l}\text { Nyomon követem a legújabb model- } \\
\text { leket (telefon, tab, játékkonzol), ennek } \\
\text { megfelelően vásárolok. }\end{array}$ & ,138 &,- 123 &, 834 & ,002 \\
\hline $\begin{array}{l}\text { Én magam is naponta használok digitális } \\
\text { eszközöket a gyermek(ek) jelenlétében. }\end{array}$ & ,201 & ,253 & ,707 &,- 006 \\
\hline
\end{tabular}


„A tévé maradt az egyetlen lehetôség, ami lefoglalta öket”

- Hatéves kor alatti gyermekek és családjuk digitális eszközhasználatának

változása a Covid19 járvány idején

\begin{tabular}{|l|c|c|c|c|}
\hline $\begin{array}{l}\text { Törekszem arra, hogy csak munkára } \\
\text { használjam a digitális eszközöket, nem } \\
\text { kikapcsolódásra. }\end{array}$ &,- 131 &, 121 &,- 010 &, 878 \\
\hline $\begin{array}{l}\text { Extraction Method: Principal Component Analysis. Rotation Method: Varimax with } \\
\text { Kaiser Normalization. }\end{array}$ \\
\hline \\
a. Rotation converged in 4 iterations.
\end{tabular}

Az 1. faktorba a „megengedő, nem szabályozó" attitűdöt mutató szülői válaszok rendeződtek, amelyek arról szólnak, hogy a gyermek unaloműzésre, megnyugtatásra, napi szinten, akár étkezések közben is megkaphatja az IKTeszközt, amelyet a szülő gyakran jutalomként ad oda és amelyet a gyermek önállóan kezelhet, de a szülő együtt is játszik a gyermekkel. Ez az attitűd és viselkedés kissé jellemzőbb az idősebb szülőkre (szülői életkor és a „megengedö, nem szabályozó" attitűd faktor korrelációja $\mathrm{r}=0,190 \mathrm{p} \leq 0,01)$ és az idősebb gyerekekre (gyermek életkora és a „megengedö, nem szabályozó" attitűd faktor korrelációja $r=0,293 \mathrm{p} \leq 0,01)$. (1. táblázat)

A válaszadó iskolázottságával összefüggésben (2. ábra) a megengedő attitűdöt valószínűbbnek találtuk az alacsonyabban iskolázott szülők körében, mint a felsőfokú végzettségűeknél $(\mathrm{p} \leq 0,01)$. Szintén összefüggést találtunk a szülő párkapcsolati státusza és a megengedő attitűd között. Az elvégzett Mann-Whitney-próba alapján az egyedülálló szülők (egy kivételével mind anyák) szignifikánsan magasabb értékeket mutatnak a megengedés terén, mint a párkapcsolatban élők $(\mathrm{p} \leq 0,01)$, azonban az alacsony elemszám miatt az eredményt korlátozottan vehetjük figyelembe, kiegyensúlyozottabb mintán kell az eredményt ellenőrizni.

\section{2. ába}

A szülő iskolai végzettsége és a „megengedö, nem szabályozó" attitüd összefüggése

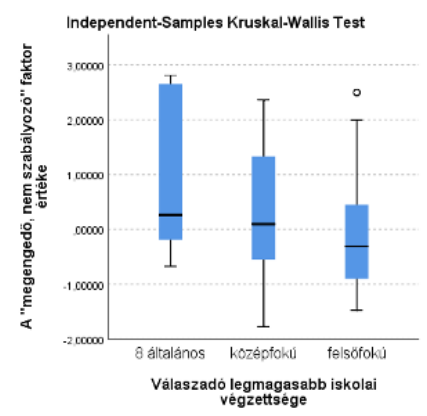

A 2. faktorba az „ellenőrző, kontrolláló” attitűdöt mutató szülői válaszok rendeződtek egybe, ahol az átlagnál magasabb faktorsúllyal szerepelt a korhatár ajánlás figyelembevétele és médiafogyasztás szoros ellenőrzése, ugyan- 
akkor a válaszadó nem zárkózik el a gyermekkel közös játéktól és gyermekének sem tiltja az IKT-használatot.

A magasabb iskolai végzettségűek az „ellenőrző, kontrolláló” attitűdöt jelentő faktorban magasabb értékkel jellemezhetők, mint a középfokú vagy általános iskolai végzettséggel rendelkezők $(\mathrm{p} \leq 0,01)$. Az „ellenőrző, kontrolláló" attitüd ugyanakkor ebben a mintában nem függ össze sem a gyermek, sem a szülő életkorával, vagy kapcsolati státuszával. (3. ábra)

\section{3. ábra}

A válaszadó legmagasabb iskolai végzettsége alapján mért különbségek az „ellenörző, kontrolláló" szülői viszonyulással összefüggésben

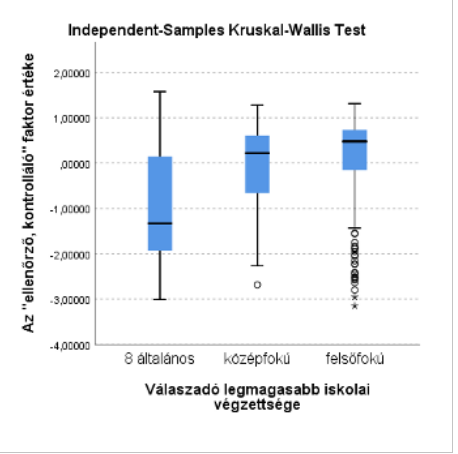

A 3. faktorba a „geek E gamer" (kocka) szülői válaszok rendeződtek, ahol legnagyobb faktorsúllyal szerepelt a technológiai fejlődés nyomonkövetése (0.834) és az IKT-használat gyakorisága $(0,707)$, közepes faktorsúllyal a gyermekkel való együttjátszás $(0,321)$. A "geek E gamer" faktor sem a vizsgált gyermek, sem a szülő életkorával vagy iskolai végzettségével nem mutatott összefüggést, ugyanakkor a nagyon kevés férfi válaszadó ebben a faktorban a nőknél magasabb értékkel jellemezhető ( $\mathrm{p} \leq 0,001)$.

Végül a 4. faktorba azok a "digitális luddita” hozzáállást tükröző válaszok kerültek, amelyek átlag fölötti faktorértékkel tartalmazták az IKT-eszközök minimális otthoni használatát, emellett a szülő maga sem igazán követi a technológiai újításokat, nem nagyon engedi a gyermeknek a digitális eszközhasználatot („Gyermekem napi szinten használt valamilyen médiaeszközt” faktorsúlya -0.91), de azért például étkezés közben odaadja az eszközt („Étkezések alatt engedem a digitális eszközök használatát” faktorsúlya 0,215), viszont inkább nem ellenőrzi a tartalmakat („Ellenöriztük, hogy gyermekünk milyen tartalmat néz(nek) készülékei(ke)n" faktorsúlya 0.17). Ez a faktor semmilyen demográfiai jellemzővel nem mutatott összefüggést. 


\section{A pandémia hatása a családokra és az IKT használatra}

A válaszadó szülők 11\%-a nyilatkozott úgy, hogy ő vagy partnere elvesztette munkáját a járvány okozta korlátozások következtében. A középfokú végzettségü válaszadók kétszer annyian (13,2\%-ban) veszítették el a munkájukat, mint a felsőfokú végzettségüek (6,1\%). A válaszadók 32\%-a kérdőív kitöltése idején továbbra is bejárt dolgozni - ez sokkal valószínűbb volt a középfokú $(54,4 \%)$ mint a felsőfokú végzettség esetén (32,5\%), utóbbiak nagy része $(65,3 \%)$ távolléti munkarendben, otthonról folytatta a munkáját. A válaszadók között 19 anya volt a pandémia alatt gyes-en, gyed-en, a többi válaszadónak a gyermeknevelési intézmények 2020. márciusi bezárásával meg kellett oldani az érintett gyermekek napközbeni felügyeletét, csak 11\%-uk bízta a gyermeket az intézményi ügyeletre. A válaszadók 69\%-a önmaga oldotta meg a gyerekek felügyeletét - itt a válaszok a válaszadók szülői státusza alapján tértek el. Az apáknak 40,8\%-a, míg az anyák 70,9\%-a maradt otthon a gyerekekkel (az esetek nagy részében home office keretében), azonban az apák kis száma $(\mathrm{N}=10)$ miatt ez az összehasonlítás korlátozottan figyelembe vehetö.

A válaszadók szerint a gyermekek jelentős része (44\%) a korlátozások bevezetése után is ugyanannyi időt töltött digitális médiaeszközök használatával, mint előtte. Több mint a gyermekek 46\%-ának nőtt a képernyőhasználata, 29\%-uk kicsivel többet, 17\%-uk sokkal többet nézi/nyomkodja az IKT-eszközöket, mint korábban, és mindössze 8,9\%-nál csökkent a képernyőidő. (4. ábra).

\section{4. ábra}

A gyermekek digitális eszközhasználatának változása a pandémia alatt

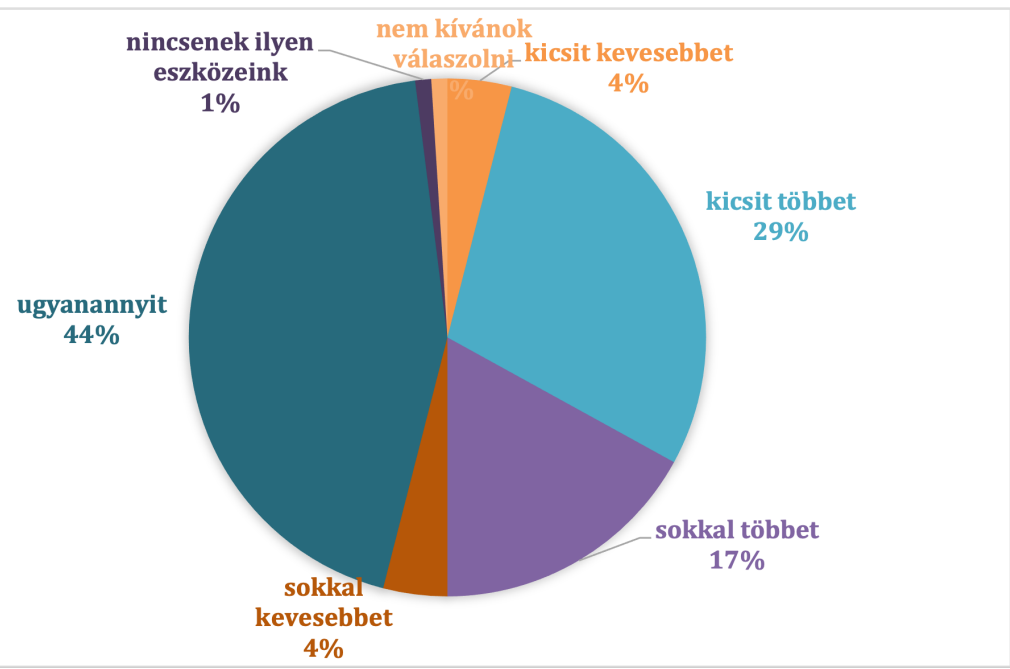


A képernyőidő változása a gyermek életkorával összefüggésben enyhe, de szignifikáns pozitív korrelációt mutat $(\mathrm{r}=0,169, \mathrm{p} \leq 0,001)$ vagyis az idősebb gyermekek digitális eszközhasználata jobban növekedett a pandémia alatt, mint a kisebbeké ( $\mathrm{r}=0,169, \mathrm{p} \leq 0,001)$, akiknél korábban is jobban korlátozták a használatot. Ennél erősebb az összefüggés azonban a szülő digitális eszközökkel kapcsolatos általános beállítódása és gyakorlata között, melyet a korábbiakban négy faktorba soroltunk. Ezek közül két faktor mutat szignifikáns korrelációt a gyermekek pandémia alatti digitális eszközhasználatának változásával. Nem meglepő módon a „megengedő, nem szabályozó” attitűd közepes erősségű pozitív korrelációt mutat az képernyőidő változásával $(\mathrm{r}=0,437$, $\mathrm{p} \leq 0,001)$, míg az „ellenőrző, kontrolláló” attitűdöt összefogó faktor enyhe negatív korrelációban áll az említett változóval $(\mathrm{r}=-0,155, \mathrm{p} \leq 0,001)$. Tehát aki eddig alapvetően nem szabályozta, nem kontrollálta a gyermek médiaeszköz-használatát, annak a gyermeke a bezártság alatt növelte a képernyőidőt, míg a tudatosan szabályozó, kontrolláló (de nem teljesen tiltó) hozzáállás a képernyőidő enyhe csökkenésével járt a kényszerü otthonlét ideje alatt.

Egy másik kérdésblokkban külön megkérdeztük a szülőket a digitális eszközhasználat és a pandémia okozta változások összefüggéseiről, az ezzel kapcsolatos nézeteikről, tapasztalataikról, arra kérve őket, hogy egy ötfokú skálán jelöljék, mennyire igazak rájuk a munka és gyereknevelés összeegyeztetésével kapcsolatos kijelentések a pandémia időszakában (például: „Munkám miatt kevesebb idő jut/jutott a gyermekeimre”, „Arra törekszem, hogy gyermekem kivánságát helyezzem elötérbe").

A válaszadó szülők - saját bevallásuk szerint - a járvány idején is törekedtek arra, hogy a gyermekükkel való kapcsolatot és a gyermek kívánságait helyezzék előtérbe a munkával szemben (átlag ötfokú skálán 3,88). Előfordult azonban, hogy felborult a napirend (átlag 2,87) és kevesebb idő jutott a gyermekeikre (átlag 2,23), ezért időnként többet engedték a médiaeszközök használatát, mint korábban (átlag 2,79). A demográfiai háttérváltozók és a korábban feltárt digitális eszközökkel kapcsolatos általános attitűdök közül a "megengedő, nem szabályozó" attitűd újból erős, szignifikáns korrelációt mutat a pandémiához köthető változások irányával - aki eddig is megengedő volt, az most még jobban ráhagyta gyermekére a médiahasználatot. Minél inkább jellemezte a szülőt ez a megengedő hozzáállás, annál inkább úgy nyilatkozott, hogy munkája miatt most még kevesebb ideje jutott a gyermekére $(r=0,417, p \leq 0,001)$, többet is engedte neki a médiahasználatot $(r=0,715$, $\mathrm{p} \leq 0,001)$, sőt ő maga többször adott gyermeke kezébe digitális eszközt, mint korábban $(r=0,607, p \leq 0,001)$. A megengedéssel összefüggésben jobban megjelent az is, hogy a családoknak felborult a napirendje a pandémia alatt $(\mathrm{r}=0,409, \mathrm{p} \leq 0,001)$. Ugyanez az „ellenörzö, kontrolláló" attitüddel pont ellenkezőleg függött össze, noha a korrelációk itt sokkal gyengébbek. Minél inkább kontrolláló volt a megkérdezett szülő, annál kevésbé esett szét a családi napirend $(\mathrm{r}=-0,116, \mathrm{p} \leq 0,01)$, annál kevésbé volt jellemző, hogy a szülő maga adott digitális eszközt a gyereknek megnyugtatásul $(\mathrm{r}=-0,130, \mathrm{p} \leq 0,01)$, és így 
a gyermekek képernyőhasználata a már említett módon nem nőtt, hanem csökkent $(\mathrm{r}=-0,155, \mathrm{p} \leq 0,001)$

\section{Szülői megjegyzések és kiegészitések}

A kérdőív végén a szülőknek lehetőségük volt válaszaikhoz megjegyzést, kiegészítést füzni. A válaszadók közül 65 fő (16\%) élt ezzel a lehetőséggel. Azok között, akik válaszoltak erre a kérdésre, a válaszok első csoportja (26\%) a családi jellemzők és változások részletezése volt, például, hogy a válaszadó gyes-en, gyed-en van és ezért nem érintette őket annyira a bezártság, vagy hogy egyik szülő elveszítette az állását, vagy hogy a nagyszülők nem elérhetőek a járvány miatt, illetve, hogy a szülő egyedül neveli a gyermekét és ez még nehezebb így a bezártság alatt. A válaszok nagy része (32\%) az általános képernyőhasználattal kapcsolatos, például, hogy az adott család ebben mennyire szigorúan, milyen óraszámban engedélyezi a gyermeknek az IKTeszközhasználatot, de akár a tévénézést. például: „A fószabály szerint csak szombaton lehet tabletezni egy órát. Ez a járvány miatt nem változott." vagy „Digitális eszköz használata alatt esetünkben azt értem, hogy a laptopon nézhet a korának megfelelö, általam kiválasztott mesét, velem együtt, nem azt, hogy felügyelet nélkül és játékra használhatja.. A válaszok egy kis része (5\%) általánosságban szólt a gyermeknevelésről, például arról, hogy „Szerintem semmi sem káros, ha mértékkel, együtt csináljuk a gyermekkel és minden lehet káros, ha mértéktelenül, felügyelet nélkül hagyjuk rá." A válaszok jelentős része (33\%) részletezte a járvány okozta változásokat a médiahasználattal összefüggésben. Egy hosszabb idézettel szeretnénk érzékeltetni az otthoni munkavégzés és a gyermeknevelés összeegyeztetésének tipikus, sokak által megélt nehézségeit: „Mindig nagyon odafigyeltem arra, hogy a lehetö legkevesebb inger érje a gyerekeimet a digitális világból, amíg ilyen kicsik. Viszont a járvány óta a home office és az állandó meetingek teljesen felboritották az életünket. Sajnos sokszor elöfordult, hogy a férjemmel egyszerre kellett belépni a meetingre és a TV maradt az egyetlen lehetöség, ami lefoglalta öket. Ez nagyon frusztráló és nehéz máshogy megoldani, mert a család többi tagja vidéken él és nem tud napi szinten segiteni. Remélem, hogy hamarosan vége lesz ennek és visszakerül az életünk a normális kerékvágásba. Mai napig küzdünk vele, hogy ebben a helyzetben legalább a hétvégén kerüljük ezeket az eszközöket." A válaszok kis része (4\%) a kérdőívre magára vonatkozott, például dicsérve vagy további javaslatokat adva a fejlesztésre.

\section{Az eredmények elemzése}

Eredményeink részben megerősítik, ugyanakkor nagyban árnyalják a korábbi kutatási eredményeket a kisgyermekek digitális eszközhasználata és a szülők ezzel kapcsolatos tudatossága tekintetében. Ahogyan a korábbi kutatások, úgy mi is azt találtuk, hogy a kisgyermekek viszonylag korán talál- 
koznak digitális médiaeszközökkel és sokan már hatéves koruk előtt saját IKT-eszközzel rendelkeznek (B. Német et al., 2021; Janek, 2019; Koscsóné \& Kiss, 2020). Kutatásunkban azonban a kényelmi mintavétel olyan szülőket toborzott össze, akik a korábbi kutatásokkal ellentétben sokkal tudatosabbnak és megfontoltabbnak tünnek a gyermekek digitális eszközhasználata kérdésében. Ha a skálán értékelt kérdések átlagait vizsgáljuk, akkor azt mondhatjuk, hogy a szülők közepesnél nagyobb mértékben törekednek a médiaeszközök kontrolljára, a korhatár ellenőrzésre, és alig, vagy csak ritkán alkalmazzák a digitális eszközöket unaloműzésre vagy jutalmazásra. A skálán értékelt kérdések faktoranalízise ugyanakkor fontos szemponttal gazdagítja a képernyőidő szabályozásának kérdéseit.

Az általunk feltárt négy faktor kettő, egymástól elvileg független dimenzióját ragadja meg a szülők digitális technológiához való viszonyának. A „kocka - luddita” dimenzió az IKT-eszközökkel kapcsolatos kompetenciákat és magabiztosságot jeleníti meg, két szélsőséges végpontján a technológiai fejlődést követő, kihasználó „kockákkal” és a technológiát csak kényszerből használó, nem túl kompetens „ludditákkal”. A digitális eszközök és a gyereknevelés kapcsolata jelenik meg a másik dimenzióban, ahol a két végponton a „megengedő, nem szabályozó" és az „ellenőrző, korlátozó” attitűdök állnak. Ezt a két dimenziót további kutatásokban kell kibontani, jelen kutatásnak nem ez volt a célja.

Vizsgálatunk elsősorban a megengedés- és a kontrolldimenzió fontosságát tárta fel a pandémia viszonyában, eredményeink szerint ezek a változók függtek leginkább össze a járvány következtében megváltozott családi élettel és a gyermekek IKT eszközhasználatának változásával. Úgy tűnik, hogy azokban a családokban, ahol korábban is tudatosan korlátozták és ellenőrizték a gyermekek médiaeszköz használatát, a járvány nem okozott nagy felfordulást. A kutatásban nem vizsgáltuk, de elképzelhető, hogy ezekben a családokban egyébként is több időt fordítanak a gyereknevelésre, tudatosabbak és kompetensebbek a szülők a nehézségekkel való megbirkózásban, ezért itt a járvány okozta változások esetleg még jobban növelték az odafigyelést, a törődést. Ezt részben alátámasztja az iskolázottsággal talált összefüggés. Eredményeink szerint az alacsonyabb végzettségü szülőkre jobban jellemző volt a megengedő attitüd és így az ő gyermekeik körében jobban megnőtt a képernyőidő a pandémia alatt. A magasabban iskolázott szülők válaszai nagyobb tudatosságot és több kontrollt tükröztek a járvány előtti és alatti viselkedésre vonatkozóan, bevallásuk szerint az ő gyermekeik körében nem vagy alig nőtt a képernyőidő a korlátozások alatt. Nem szabad azonban elfelejtenünk, hogy a felsőfokú végzettségű válaszadók esetleg sokkal tudatosabbak abban is, hogy mit várnak el tőlük egy ilyen kutatásban, és válaszaik nem annyira a valóságot, mint a társadalmi és pedagógiai elvárásoknak való megfelelést tükrözik. 


\section{Összegzés}

Az általunk vizsgált családok mindegyike digitális eszközhasználó, azonban az ehhez kapcsolódó kompetencia és magabiztosság, valamint a szülői tudatosság mértéke egyénileg változó. Az általunk megkérdezett szülők többsége tudatosan korlátozza a gyermekek IKT használatát, ugyanakkor az alacsonyabban iskolázott, egyedülálló és/vagy idősebb szülőket alapvetően megengedőbbnek és kevésbé korlátozónak találtuk.

A pandémia jelentős változásokat hozott a családok életében. A szülők nagy része otthoni munkavégzésre kényszerült és ezzel egyidőben a kisgyermekeket is elsősorban otthon, a szülők látták el. Ez a változás a családok többségében megnövelte a leterheltséget, és a szülők sokszor érezték, hogy nem jut elég idő, figyelem a gyermekekre. Az, hogy ez mennyire jelentett lazább kontrollt a gyermekek médiahasználatában, az eredmények szerint attól függött, hogy alapvetően mennyire volt a szülő az IKT-használatban megengedő vagy kontrolláló.

Az általánosságban megengedőbb szülők a járvány alatt még megengedőbbé váltak, az ő gyermekeiknél nőtt az eszközhasználat, amíg a kontrollálóbb szülők gyermekei esetén esetleg még csökkent is. Mindez nem a járvány és a megnövekedett terhek, hanem az alapvető szülői kompetenciák és tudatosság fontosságát emeli ki a gyermekek médiahasználatával összefüggésben. Fontosnak tartjuk ezért a szülők digitális kompetenciáinak és tudatosságának növelését, melyet egyaránt kezdeményezhetünk a gyermeknevelési intézményeken és a gyermekjólléti szolgáltatásokon vagy az egészségügyi szolgáltatásokon (például védőnői hálózat) keresztül.

Kutatásunk számos korláttal rendelkezik. Legnagyobb korlátja a minta kiegyensúlyozatlansága, az alacsonyabb végzettségű és az egyedülálló válaszadók, valamint az apák alacsony aránya. Jelen kutatásban nem volt módunk reprezentatív mintát összeállítani, a pénzügyi forrás hiánya a kényelmi mintavételt tette lehetővé. Mindazonáltal eredményeink hozzájárulhatnak további, reprezentatív kutatások tervezéséhez, a feltárt összefüggések validálása és pontosítása céljából.

\section{Irodalom}

Anderson, C.A., Bushman, B. J. (2001). Effects of violent video games on aggressive behavior, aggressive cognition, aggressive affect, physiological arousal, and prosocial behavior: a meta-analytic review of the scientific literature. Psychological Science, 12(5), 353-359. https://doi.org/10.1111/1467-9280.00366

B. Németh, M., Hódi, Á., Juhász, F., Sárik, A., \& Tóth, E. (2021). Szülők véleménye az óvodáskorú gyermekek IKT-eszköz használatának negatív és pozitív hatásairól. Gyermeknevelés Tudományos Folyóirat, 9(1), 8-38. https://doi. org/10.31074/gyntf.2021.1.8.38 
Bérubé, A., Clément, M. È., Lafantaisie, V., LeBlanc, A., Baron, M., Picher, G., Turgeon, J., Ruiz-Casares, M. \& Lacharité, C. (2020). How societal responses to COVID-19 could contribute to child neglect. Child Abuse E Neglect, 104761. https://doi.org/10.1016/j. chiabu.2020.104761

Greaves, S., Imms, C., Krumlinde-Sundholm, L., Dodd, K. \& Eliasson, A. C. (2012). Bimanual behaviours in children aged 8-18 months: a literature review to select toys that elicit the use of two hands. Research in Developmental Disabilities, 33(1), 240-250. https://doi.org/10.1016/j.ridd.2011.09.012

Hastings, E. C., Karas, T. L., Winsler, A., Way, E., Madigan, A. \& Tyler, S. (2009). Young children's video/computer game use: relations with school performance and behavior. Issues in Mental Health Nursing, 30(10), 638-649. https://doi. org/10.1080/01612840903050414

Healey, A. \& Mendelsohn, A., AAP COUNCIL ON EARLY CHILDHOOD (2019). Selecting Appropriate Toys for Young Children in the Digital Era. Pediatrics, 143(1):e20183348. https://doi.org/10.1542/peds.2018-3348

Hsieh, H. C. (2008). Effects of ordinary and adaptive toys on pre-school children with developmental disabilities. Research in Developmental Disabilities, 29(5), 459-466. https://doi.org/10.1016/j.ridd.2007.08.004

Janek, N. (2019). „Google-bácsi mindent tud” - eredmények és tapasztalatok az óvodások digitális eszköz- és internethasználatának vizsgálatáról. Gyermeknevelés Tudományos Folyóirat, 7(2-3), 95-110. https://doi.org/10.31074/20192395110

Kabali, H. K., Irigoyen, M. M, Nunez-Davis, R., et al. (2015). Exposure and use of mobile media devices by young children. Pediatrics, 136(6), 1044-1050.

Kardaras, N. (2017). A képernyő rabjai. Jaffa Kiadó.

Király, O., Potenza, M. N., Stein, D. J., King, D. L., Hodgins, D. C., Saunders, J. B., Griffiths, M. D, Gjoneska, B., Billieux, J., Brand, M., Abbott, M. W., Chamberlain, S. R., Corazza, O., Burkauskas, J., Sales, C. M. D., Montag, Ch., Lochner, Ch. Grünblatt, E. \& Demetrovics, Zs. (2020). Preventing problematic internet use during the COVID-19 pandemic: Consensus guidance. Comprehensive Psychiatry, 100, 152180. https://doi.org/10.1016/j.comppsych.2020.152180

KSH (2011). A 2011-es népszámlálási adatok adattáblái. A családtípusok jellemzöi. http://www.ksh.hu/nepszamlalas/tablak_csaladtipusok_jellemzoi (2021. 06. 13.)

Konok, V., Peres, K., Ferdinandy, B., Jurányi, Z., Bunford, N., Ujfalussy, D. J., Réti, Z., Kampis, G., \& Miklósi, Á. (2020). Hogyan hat a mobileszköz-használat az óvodásokfigyelmére és társas-kognitív készségeire? Gyermeknevelés Tudományos Folyóirat, 8(2), 13-31. https://doi.org/10.31074/gyntf.2020.2.13.31

Koscsóné Kolkopf, J., \& Kiss, H. (2020). „Digitális Honfoglalás” avagy 0-3 évesek a digitális világban. Gyermeknevelés Tudományos Folyóirat, 8(2), 202-218. https:// doi.org/10.31074/gyntf.2020.2.202.218

Lee, S. J., Ward, K. P., Chang, O. D., \& Downing, K. M. (2021). Parenting activities and the transition to home-based education during the COVID-19 
„A tévé maradt az egyetlen lehetôség, ami lefoglalta öket”

- Hatéves kor alatti gyermekek és családjuk digitális eszközhasználatának változása a Covid19 járvány idején

pandemic. Children and Youth Services Review, 122, 105585. https://doi. org/10.1016/j.childyouth.2020.105585

Lénárd, A. (2015). A digitális kor gyermekei. Gyermeknevelés Tudományos Folyóirat, 3(1), 74-83. https://doi.org/10.31074/gyntf.2015.1.74.83

Milteer, R. M., Ginsburg, K.R; Council on Communications and Media; Committee on Psychosocial Aspects of Child and Family Health. (2012). The importance of play in promoting healthy child development and maintaining strong parentchild bond: focus on children in poverty. Pediatrics, 129(1). www.pediatrics.org/ cgi/content/full/129/1/e204

Montag, C. \& Elhai, J. D. (2020). Discussing digital technology overuse in children and adolescents during the COVID-19 pandemic and beyond: On the importance of considering Affective Neuroscience Theory. Addictive behaviors reports, 12, 100313. https://doi.org/10.1016/j.abrep.2020.100313

Pagani,L.S., Fitzpatrick, C., Barnett, T.A.\& Dubow, E. (2010). Prospectiveassociations between early childhood television exposure and academic, psychosocial, and physical well-being by middle childhood. Archives of Pediatrics \& Adolescent Medicine, 164(5), 425-431.

Parish-Morris, J., Mahajan, N., Hirsh-Pasek, K., Golinkoff, R. M. \& Collins, M. F. (2013). Once upon a time: parent-child dialogue and storybook reading in the electronic era. Mind, Brain \& Education, 7(3), 200-211. https://doi.org/10.1111/ mbe.12028

Porkolábné Balogh, K. (1992). Kudarc nélkül az iskolába. AlexTypo.

Sosa, A. V. (2016). Association of the type of toy used during play with the quantity and quality of parent-infant communication. JAMA Pediatrics,170(2), 132-137. https://doi.org/10.1001/jamapediatrics.2015.3753

Zeng, N., Ayyub, M., Sun, H., Wen, X., Xiang, P., \& Gao, Z. (2017). Effects of physical activity on motor skills and cognitive development in early childhood: a systematic review. BioMed Research International, 2017. https://doi.org/10.1155/2017/2760716 


\section{F. Lassú, Zs. \& Megyeriné Fácska, J.}

\section{'Television was the only way left to entertain them' - Changes in the use of ICT and media devices in families of young children during the Covid-19 pandemic}

The coronavirus-19 epidemic that began in 2020 resulted in the complete shutting down of institutions serving children in Hungary in the spring of 2020. Parents worldwide had to take care of their children at home and this very often upended family life. Caring for young children at home and reconciling work was a challenge for families which often led to an increase in children's use of digital devices. In our study, we examined parents raising children under the age of $\operatorname{six}(\mathrm{N}=391)$ for general and pandemic "emergency" views and practices related to their young children's use of media, using an online questionnaire and convenience sampling. Our results show that the majority of young children in the families surveyed were ICT device users even before 2020, and during the pandemic an increase in screen time in $46 \%$ of the children studied was recorded. Regarding the general regulation of digital device use, the research revealed four factors, of which the "permissive, non-regulatory" and "controlling, regulating" factors showed a correlation with epidemic-related changes. The general permissive attitude (which is more common among older and less educated parents and older children) was also associated with an increase in ICT device use among children during the epidemic, while general parental control, even during the crisis, did not allow children to use screens excessively. Our results call for awareness-raising among parents about the excessive use of media by young children.

Keywords: Covid-19 epidemic, early childhood, excessive use of ICT/digital media devices, parental control

F. Lassú Zsuzsa: https://orcid.org/0000-0003-2213-0810 